\title{
Populism, Anarchism and the Movement of the Squares
}

\author{
Todd Wolfson
}

Rutgers University, New Brunswick, USA, twolfson@rutgers.edu, toddwolfson.org

Abstract: This reflection is a review of Paolo Gerbaudo's book The Mask and the Flag: Populism, Citizenism, and Global Protest (2017).

Keywords: Social Movements, Populism, Horizontality, Movement of the Squares, Anarchism

During the Democratic National Convention of 1886 in Chicago, William Jennings Bryan gave one of the most rousing speeches in American history. Building a powerful alliance in his bid to be president, Bryan captured the imagination of working people in his famous "Cross of Gold" speech. At the end of the speech, taking aim at the $1 \%$ of his day, Bryan exclaimed, "If they dare to come out in the open field and defend the gold standard as a good thing, we shall fight them to the uttermost, having behind us the producing masses of the nation and the world. Having behind us the commercial interests and the laboring interests and all the toiling masses, we shall answer their demands for a gold standard by saying to them, you shall not press down upon the brow of labor this crown of thorns. You shall not crucify mankind upon a cross of gold". (Encyclopedia Britannica 1968.)

This speech - which pits the many against the few - was one of the defining moments of the Populist movement in the United States, which flourished at the end of the $19^{\text {th }}$ century. The power of the American Populist movement as well as the right-wing variety that flourished across Europe in the $20^{\text {th }}$ century has shaped our imagination of populism as a political strategy that connects with 'the people' and juxtaposes their interests to the interests of the elite, oft-times through a cult-like political leader.

While this experience of the late $19^{\text {th }}$ and $20^{\text {th }}$ centuries has shaped the way we understand populist politicians and movements, in the last 25 years we have begun to see a new logic of organizing and activism, which has imprinted movements and political parties across the spectrum. Given this shifting terrain, Paolo Gerbaudo's recent book The Mask and the Flag: Populism, Citizenism and Global Protest takes aim at the concept of populism with the goal of reinterpreting the theory in an era marked by increasing economic and political desperation.

At the heart of Gerbaudo's theory of populism is the seeming contradiction within the "movement of the squares" from 2011-2016, between the tendency towards a neo-anarchist logic of horizontality and leaderlessness on one hand, and the growth of party-like apparatuses that have fought for state power while harnessing concepts of nationalism, leadership and party structure on the other. These two contradictory tenets have come into conflict but have ultimately played a productive role in defining the movements of the $21^{\text {st }}$ century from Spain and Brazil to the United States and Turkey. Gerbaudo captures this contradiction at the heart of the movement through the twin symbols of the mask and the flag. For Gerbaudo, the infamous Guy Fawkes mask symbolises the at times dominant neo-anarchist, horizontalist current of contemporary movements, while the flag symbolises "traditional statist strategies". For Gerbaudo, these twin logics synthesise into the new politics of citizenism, which he defines as "an emerging ideology of the indignant citizen, that pits the self-organized citizenry against economic and political oligarchies, and pursues the reclamation and expansion of citizenship..." (3) 
The book, which is lucidly written and thoughtfully organised, is structured around a series of case studies. These studies range from the revolts in North Africa and the Middle East and the wave of protests in Spain and Greece to the emergence of Occupy movements and subsequent revolts that took place in Turkey, Brazil and France. There are many productive concepts to be unearthed in Gerbaudo's theoretical frame and extensive research agenda. The most compelling aspect of The Mask and the Flag is Gerbaudo's ability to paint on a large canvas. Like many social movement scholars that have written about the recent waves of struggle (Juris 2008; Dyer-Witheford 1999; Hardt and Negri 2004; Funke 2012; Wolfson 2014) Gerbaudo sees an emerging logic that ties together what he calls the movement of the squares from 2011-2016. The book is singular in that Gerbaudo is the first to really examine the relationship of anarchism or what he calls neo anarchism and populism in this period of struggle.

While the large tableau is one of the strengths of The Mask and the Flag, the book is also strong in the rigour of the research. The movements that Gerbaudo brings to life from Tunisia and New York to Sao Paolo are clear and powerful and the attention to detail is impressive. In this way Gerbaudo is able to theorise on a grand scale while offering a rich and nuanced picture of contemporary movements on the ground.

There were two places where I had arguments with The Mask and the Flag. The first came at the end of the first chapter where Gerbaudo makes an argument for a new class alignment within contemporary movements led by what he calls the "New Poor" or "squeezed middle." While he does not spend a lot of time working through this argument and does not offer the reader a precise understanding of what this new class formation might mean for contemporary movements, he does make some big claims, arguing that the new poor is the new universal class and thus likening it to Marx's industrial proletariat. While there is clearly not enough class analysis in social movement studies, and I applaud Gerbaudo for including critical questions about class in contemporary movements, I think this part of the book needed more theoretical clarity. Specific questions emerge about the movement of the squares, particularly if it is led by this new class formation. If the new poor is the new protagonist, what does that mean? How do the new poor relate to the long-standing poor, the precariat, and the industrial working class? How does this new poor lead in the interests of all of society? Does the logic and class position of the new poor lead to effective organisation and the possibility for broader fronts of struggle or historical blocs? Does the new poor's vision of society alienate other sectors of the broad working class or unite them? These questions and others were largely left unanswered by Gerbaudo and would have strengthened his analysis and helped the reader to understand the possibilities in social struggles to come.

Building on the above point, at times I wondered whether Gerbaudo was too close to the movement of the squares. By this I mean to say that he offered a deep understanding of the emergence and trajectory of the movement and shows many aspects of this movement formation quite convincingly, but as I read this work, I wanted more substantive critique. While we can't do everything in one book, I still wanted to understand both the strengths and the weaknesses of the movement of the squares from his perspective. In this sense, at times I felt that the book came off as too laudatory; correspondingly, Gerbaudo's analysis hewed too closely to the vision of the movements he studied, and therefore he wasn't able to fully reckon with the strengths and weaknesses. To be fair, Gerbaudo did talk about these weaknesses, and in one chapter he marked some of the limits, but this is not fully attenuated nor consistently revisited throughout the work. A more nuanced grappling with some of the failures of the logic of citizenism would strengthen this work and help us look forward to the next period, and the ways movements are reinterpreting the logic of the squares.

The Mask and the Flag is a welcome contribution to the literature on contemporary movements. Gerbaudo has the artful ability to both theorise at a grand scale and offer rich details that help the reader to feel as though they are experiencing the movement while also reckoning with a sweep of history. Furthermore, Gerbaudo offers an original and fresh engagement with movement theory, bringing to life some new and exciting facets of contemporary movements. This is particularly so in his analysis of populism and his understanding of the contradictory logic at the heart of the movement of the squares, which puts neo anar- 
chism in dialogue with a state-oriented populism. This reckoning is fruitful and certainly has paved the way for the engagement with electoral politics from Italy and Spain to England and the U.S. that emerged on the heels of the period of protest he eloquently depicts. For this reason, Gerbaudo is able to plant a flag and push the field forward as we discuss the movements of tomorrow.

\section{References}

Dyer-Witheford, Nick. 1999. Cyber-Marx: Cycles and Circuits of Struggle in High Technology Capitalism. Champaign, IL: University of Illinois Press.

Encyclopedia Britannica. 1968. The Annals of America: 1895-1904: Populism, Imperialism, and Reform Vol. 12. Chicago: Encyclopedia Britannica Inc.

Funke, Peter. 2012. The Global Social Forum Rhizome: A Theoretical Framework. Globalizations 9(3): 339-351.

Gerbaudo, Paolo. 2017. The Mask and the Flag: Populism, Citizenism and Global Protest. Oxford: Oxford University Press.

Hardt, Michael and Antonio Negri. 2004. Multitude: War and Democracy in the Age of Empire. New York: Penguin Press.

Juris, Jeffrey. 2008. Networking Futures: The Movement against Corporate Globalization. Durham: Duke University Press.

Wolfson, Todd. 2014. Digital Rebellion: The Birth of the Cyber Left. Urbana: University of Illinois Press.

\section{About the Author}

\section{Todd Wolfson}

Todd Wolfson is Associate Professor in the Department of Journalism and Media Studies at Rutgers University. 